\title{
IMPLEMENTASI PLATFORM DIGITAL SEBAGAI MEDIA PEMBELAJARAN DARING DI MI MUHAMMADIYAH PK KARTASURA PADA MASA PANDEMI COVID-19
}

\author{
Angga Eka Yuda Wibawa \\ Universitas Islam Negeri Raden Mas Said Surakarta \\ Email: anggaeyw17@gmail.com
}

\begin{abstract}
ABSTRAK
Penelitian ini bertujuan untuk menjelaskan pemanfaatan berbagai platform digital sebagai media pembelajaran pada masa pandemi covid-19 di MI Muhammadiyah PK Kartasura. Penelitian ini merupakan bagian penting atas adanya perubahan proses kegiatan pembelajaran tatap muka menjadi pembelajaran daring/online dengan bantuan beberapa platform digital yang dikeluarkan Kementerian Pendidikan dan Kebudayaan sebagai media pembelajaran. Metode yang digunakan pada penelitian ini adalah metode kajian pustaka. Data penelitian yang dikumpulkan berupa data studi literatur. Sumber data yang digunakan diambil dari berbagai referensi yang relevan dengan penelitian seperti buku, jurnal penelitian, dan manual book atau buku panduan penggunaan beberapa platform digital. Teknik analisis data yang digunakan adalah analisis isi (content analysis), yaitu mengkaji informasi utama yang dibahas dalam referensi, mengaitkan dengan setiap topik yang dibahas, kemudian pemetaan konsep dalam bentuk perbandingan dari setiap data penelitian. Hasil dari penelitian ini diharapkan memberi kontribusi dalam memudahkan sekolah, guru, dan siswa memanfaatkan beberapa platform digital yang dikeluarkan Kementerian Pendidikan dan Kebudayaan sebagai media pembelajaran selama covid-19.
\end{abstract}

Kata kunci: platform digital; manual book; pembelajaran daring.

\section{ABSTRACT}

This study aims to explain the use of various digital platforms as learning media during the COVID-19 pandemic at MI Muhammadiyah PK Kartasura. This research is an important part of the change in the process of face-to-face learning activities into online learning with the help of several digital platforms issued by the Ministry of Education and Culture as learning media. The method used in this study is a literature review method. Research data collected in the form of literature study data. The data sources used were taken from various references relevant to research such as books, research journals, and manuals or guidebooks for the use of several digital platforms. The data analysis technique used is content analysis, which examines the main information discussed in the reference, relates it to each topic discussed, then concept mapping in the form of a comparison of each research data. The results of this study are expected to contribute to making it easier for schools, teachers, and students to utilize several digital platforms issued by the Ministry of Education and Culture as learning media during the Covid-19.

Keywords: digital platform; manuals; online learning.

\section{Pendahuluan}

Pandemi Covid-19 yang merebak di Indonesia praktis membuat banyak aktivitas tidak bisa berjalan normal bahkan terhenti, termasuk di sekolah/madrasah. Belum adanya pengetahuan yang cukup tentang virus ini membuat banyak pihak tidak mau mengambil risiko untuk melaksanakan berbagai kegiatan, termasuk sekolah atau lembaga pendidikan yang juga tidak bisa melaksanakan kegiatan pembelajaran tatap muka (luring) sebagaimana biasanya. Hal ini juga berdampak di beberapa Sekolah Dasar/Madrasah Ibtidaiyah di Kabupaten Sukoharjo. Kegiatan pembelajaran sempat dihentikan total untuk beberapa waktu, meskipun pada waktu yang lain dilaksanakan juga uji coba PTM (Pembelajaran Tatap Muka) dengan berbagai teknis. 
Pendidikan menjadi salah satu bidang yang terdampak akibat adanya Pandemi Covid-19 tersebut. Besar kecilnya dampak atau pengaruh yang disebabkan oleh adanya Pandemi Covid-19 terhadap sekolah sangatlah bervariasi di setiap wilayah. Dengan munculnya Pandemi Covid-19 kegiatan belajar mengajar yang semula dilaksanakan di sekolah kini menjadi belajar di rumah melalui daring. Pembelajaran daring dilakukan dengan disesuaikan kemampuan masing-masing sekolah. Belajar daring (online) dapat menggunakan teknologi digital seperti google classroom, rumah belajar, zoom, video converence, telepon atau live chat dan lainnya. Beberapa sekolah yang belum dapat menyelenggarakan KBM daring dapat mengembangkan kreativitas guru untuk memanfaatkan media belajar alternatif selama peserta didik belajar di rumah (Dewi, 2020).

Menghadapi situasi kritis dunia pendidikan kita tersebut, banyak terobosanterobosan yang digaungkan bahkan diujicobakan agar pembelajaran dapat berjalan meskipun tidak di satuan pendidikan. Sebagai contoh, guru-guru memberikan pembelajaran atau penugasan melalui grup Whatsapp kelas/sekolah, Google yang menjadi pusat peradaban dunia digital juga semakin menggiatkan platform Google Class Room untuk mendukung kebutuhan dunia pendidikan, pelatihanpelatihan berbasis digital dibuka baik secara gratis maupun berbayar agar para guru dapat dengan leluasa menggunakan serta mampu beradaptasi dengan berbagai platform digital berbasis pembelajaran.

Pemerintah pusat dan daerah juga semakin gencar melakukan sosialisasi terkait penggunaan bebagai media digital dalam menunjang para guru melaksanakan proses pembelajaran jarak jauh (daring). Terlebih Kementerian Pendidikan dan Kebudayaan secara resmi telah melakukan koordinasi dan dukungan bersama mitra dari sektor swasta untuk melakukan sistem belajar secara daring. Dengan teknologi internet dan perangkat pintar, kegiatan belajar mengajar kini dapat dilakukan di rumah.

Meskipun berbagai platform digital bermunculan, namun tak sedikit para guru yang mampu mengoperasionalkan, apalagi mengimplementasikan berbagai platform digital tersebut.

Penelitian ini mencoba merangkum beberapa platform digital yang diimplementasikan di MI Muhammadiyah PK Kartasura guna mengetahui bagaimana adaptasi para guru dalam mengimplementasikan platform digital pembelajaran tersebut, baik dari segi kelebihan dan kekuranganya.

\section{Metode Penelitian}

Pada penelitian ini, penulis memberikan batasan objek dan memfokuskan objek kajian pada platform digital yang diimplementasikan di MI Muhammadiyah PK Kartasura. Pendekatan yang dilakukan dalam penelitian ini yaitu penelitian kualitatif yang mencangkup upaya menelaah data empiris yang menggambarkan makna keseharian secara problematis dalam kehidupan yang dijabarkan dengan pengambilan data berupa hasil kualitatif (Fitriyah \& Luthfiyah, 2018). Pendekatan kualitatif ini biasanya bertujuan untuk menjabarkan atau mendeskripsikan sesuatu dengan metode analisis yang menekankan aspek alamiah dari rangkaian peristiwa yang diamati. Menurut Sawiningsih (2020) prosedur penelitian dengan pendekatan kualitatif akan menghasilkan data deskripsi berupa tulisan maupun ucapan hasil pengamatan subjek itu sendiri (Sawiningsih, 2020). Untuk jenis penelitian sendiri merupakan penelitian deskriptif yang mengambarkan menajemen pendidikan pesantren pada Pondok Pesantren Al-Falah Banjarbaru selama pandemi Covid-19. Untuk metode penelitian yang digunakan yaitu observasi pada objek terkait. Metode observasi yang dilakukan yaitu berupa metode mengamati sekaligus mencatat gejala yang timbul dan tampak pada objek kajian yang diteliti (Hariani, 2019). Observasi ini 
dilakukan dengan objek berupa platform digital yang diimplementasikan di MI Muhammadiyah PK Kartasura dengan melakukan pengamatan dan pengumpulan informasi untuk memantau perkembangan platform digital yang diimplementasikan di MI Muhammadiyah PK Kartasura selama pandemic covid-19 dengan hasil berupa laporan tertulis hasil pengamatan dan olah studi literatur.

\section{Platform Digital Mitra Kementerian Pendidikan dan Kebudayaan}

Pengertian platform adalah sebuah wadah digital yang banyak dipakai manusia untuk beragam keperluan. Secara sederhana, pengertian platform adalah sebuah wadah yang dipakai untuk menjalankan sebuah sistem sesuai dengan rencana program yang telah dibuat. Misalnya, untuk kegiatan pembelajaran daring, maka platform yang digunakan berbasis digitalisasi.

Sedangkan digital platform adalah sekumpulan software yang membentuk suatu sistem tertentu. Software ini bisa dibuka pada PC atau sistem android. Jika berada pada sistem android, digital platform dapat berbentuk aplikasi. Digital platform ini paling diminati dewasa ini. Pasalnya, semakin banyak pengguna smartphone akan meningkatkan trafik pada dunia maya secara otomatis.

Kementerian Pendidikan dan Kebudayaan RI telah bermitra dengan bebagai pihak untuk mengimplementasikan pembelajaran daring berbasis digital. Pada situs resmi www.belajar.id terdapat 46 (empatpuluh enam) platform digital yakni:
1) Gredu
2) Rumah Belajar
3) Google Classroom
4) Google Hangout
5) Google Slides
6) Google Sheet
7) Google Drive
8) Google Doc
9) Zoom
10) Zenius

11) Khan Academy

12) Bahaso

13) Pahamify

14) Pintaria

15) Udemy

16) Coursera

17) Ruang Guru

18) Buncee

19) $\mathrm{CK} 12$

20) DataClassroom

21) Drawp for School

22) Formative

23) LanSchool

24) Rediker

25) Schoolrunner

26) Story Jumper

27) Sycamore school

28) RealSmart

29) Tes Blendspace

30) Tynker

31) Unicheck

32) quizizz

33) Salamender Soft

34) PBS learning media

35) Knovation learning

36) Flat for Edu

37) Quipper

38) Sekolah.mu

39) Dragonlearn.org

40) PesonaEdu

41) Pijar Sekolah

42) Jateng Pintar

43) perpuskita

44) kelaspedia

45) Siswamedia

46) t-smart office

Diantara sekian banyak platform digital mitra Kementerian Pendidikan dan Kebudayaan dalam mendukung pelaksanaan pembelajaran daring di masa pandemic covid-19 tersebut, pada penelitian ini akan dibahas beberapa saja sesuai yang digunakan di MI Muhammadiyah PK Kartasura, Sukoharjo. 


\section{Profil MI Muhammadiyah PK Kartasura}

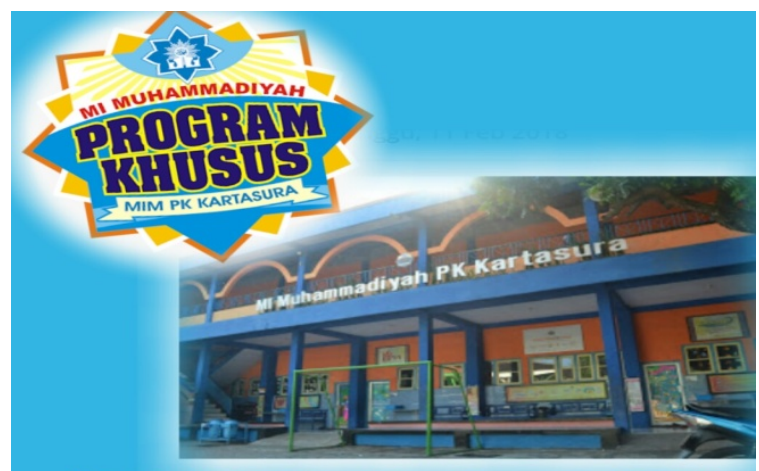

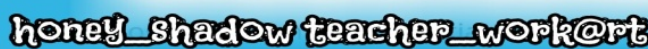

Gambar 1: Promosi Sekolah di Medsos

\section{Sejarah Berdiri dan Perkembangan}

MI Muhammadiyah PK Kartasura atau sering familiar di sebut MIM PK Kartasura berdiri pada tahun 2008 dengan bermodalkan niat, semangat dan keikhlasan tokoh Muhammadiyah Ranting Kartasura untuk menghidupkan amal usaha Muhammadiyah. MI Muhammadiyah PK Kartasura sebelumnya bernama MI Muhammadiyah Kartasura, berdiri pada tahun 1970. MI Muhammadiyah PK Kartasura ini berada di komplek Standar Kartasura yang dulu merupakan alun-alun Kartasura, milik kerajaan Kartasura (Mataram Lama). Perkembangan teori, informasi dan teknologi, serta kebutuhan masyarakat yang terus berkembang, ikut mengajak MI Muhammadiyah PK Kartasura ikut berkembang.

Pemilihan Program Khusus sebagai nama tambahan diambil setelah beberapa kali sekolah dan yayasan melakukan study banding yang dilakukan di Solo raya maupun diluar Solo dengan pertimbangan sekolah unggulan rujukan tingkat nasional. Merujuk pada perkembangan sekolah maju yang memiliki branding sekolah maka yayasan dan sekolah menambahkan nama Program Khusus pada nama MI Muhammadiyah Kartasura sebelumnya, dan akhirnya berubah nama menjadi MI Muhammadiyah PK Kartasura sampai sekarang.

Pada saat awal perkembangannya, ada beberapa tokoh yang memprakarsai berubahnya MI Muhammadiyah Kartasura menjadi MI Muhammadiyah PK Kartasura adalah Bapak Suji Suyamto, S.Pd.I Selaku ketua Ranting Muhammadiyah Kartasura dan Ustadz Nasrul Harahab, S.Pd.I. M.Pd selaku kepala madrasah pertama saat itu. Dari tokoh Muhammadiyah inilah, kemudian beliaubeliau mengagas program khusus apa saja yang akan dikembangkan di MI Muhammadiyah PK Kartasura.

Pada perkembangan awal, MI Muhammadiyah PK Kartasura berusaha membangun sekolah untuk menjadi sekolah unggul dengan wawasan global dengan membuka program khusus kelas Full Day School (FDS). Pada tahun awal sebelum menjadi program khusus jumlah total murid adalah 38 siswa, setelah dibuka program awal jumlah murid yang mendaftar sebanyak 10 siswa. Berbekal niat dan kesungguhan maka di tahun kedua siswa yang mendaftar semakin bertambah yaitu 23 siswa, dan tahun ketiga 19 siswa setelah tahun keempat jumlah siswa yang mendaftar berjumlah 56 siswa. Dari perkembangan jumlah siswa ini membuat yayasan dan sekolah optimis untuk memajukan amal usaha muhammadiyah di lingkungan kecamatan Kartasura. Akhirnya pada tahun 2020 ini MI Muhammadiyah PK Kartasura sudah memiliki jumlah siswa sebanyak 556 siswa.

Berkembangnya jumlah siswa dan pencarian jati diri pendekatan yang ingin digunakan maka MI Muhammadiyah PK Kartasura pada tahun kedua berjalan yaitu pada tahun 2010 mendapatkan tawaran pelatihan gratis dari salah satu perusahaan terkenal Nasional tentang pelatihan Multiple Intellegence yang dikembangkan oleh Munif Chatib. Pada perkembangannya setelah mengikuti pelatihan, ustadz Nasrul merasa cocok dengan pendekatan pendidikan berbasis multiple intellegence karena di sekitar Kartasura belum ada yang menggunakan pendekatan ini sebagai basis pendidikannya, maka dilaporkan hasil pelatihan ini kepada yayasan ranting Muhammadiyah Kartasura. Akhirnya diputuskan pendekatan MI Muhammadiyah 


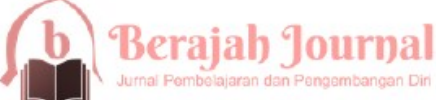

PK Kartasura menggunakan pendekatan pendidikan berupa Multiple intellegence sebagai basis pendidikan di MI Muhammadiyah PK Kartasura dengan jargon "Sekolah para Bintang".

Pada perkembangan selanjutnya, MI Muhammadiyah PK Kartasura dengan basis multiple intellegence pada tahun 2016 secara resmi mendapatkan ijin dari kementerian agama Republik Indonesia untuk menjalankan madrasah Inklusi, dan pada tahun yang sama membuka program Tahfidzul Quran sebagai program khusus yang ditawarkan. Dilanjutkan pada tahun 2017 membuka program khusus Science, Math dan English (SME) dan Creatif sebagai jawaban atas kebutuhan masyarakat pada saat itu. Tiga program khusus inilah yang sampai sekarang dipatenkan menjadi daya saing tersendiri kepada masyarakat untuk memilih bersekolah di MI Muhammadiyah PK Kartasura.

\section{Sarana dan Prasarana}

Guna mendukung proses dan program pendidikan di MI Muhammadiyah PK Kertasura, terdapat sarana dan prasarana sekolah diantaranya:

- Unit Sekolah : 2 Unit

- Ruang Kelas/Belajar : 22 ruang

- Ruang Guru/Pegawai : 2 ruang

- Ruang Perkantoran : 1 ruang

- Perpustakaan Sekolah : 1 ruang

- WC Sekolah : 8 ruang

- Ruang UKS/PKHS : 1 ruang

- Ruang Koperasi Sekolah : 1 ruang

\section{Keadaan Guru/Pegawai}

- Kepala Sekolah : 1 orang

- Guru PNS : 1 orang

- Guru Tetap : 24 orang

- Guru Honorer/GTT : 10 orang

- Guru Pendamping Khusus (Honorer) : 20 orang

- Tata Usaha : 3 orang

- Penjaga Sekolah : 3 orang

- Satpam : 2 orang

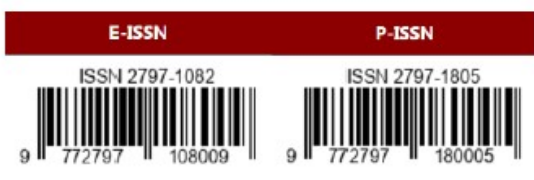

Peserta Didik Tahun Pelajaran 2020/2021

Jumlah Peserta Didik seluruhnya: 555 orang terdiri dari Siswa Putra 307 dan Siswa Putri 248 yang tersebar menjadi beberapa rombongan belajar (rombel):

- Kelas 1A : 25 siswa

- Kelas 1B : 25 siswa

- Kelas 1C : 15 siswa

- Kelas 1D : 21 siswa

- Kelas 2A : 29 siswa

- Kelas 2B : 29 siswa

- Kelas 2C : 20 siswa

- Kelas 2D : 19 siswa

- Kelas 3A : 16 siswa

- Kelas 3B : 22 siswa

- Kelas 3C : 19 siswa

- Kelas 3D : 20 siswa

- Kelas 4A : 29 siswa

- Kelas 4B : 29 siswa

- Kelas 4C : 29 siswa

- Kelas 4D : 22 siswa

- Kelas 5A : 32 siswa

- Kelas 5B : 32 siswa

- Kelas 5C : 32 siswa

- Kelas 6A : 29 siswa

- Kelas 6B : 29 siswa

- Kelas 6C : 32 siswa

\section{Program Khusus}

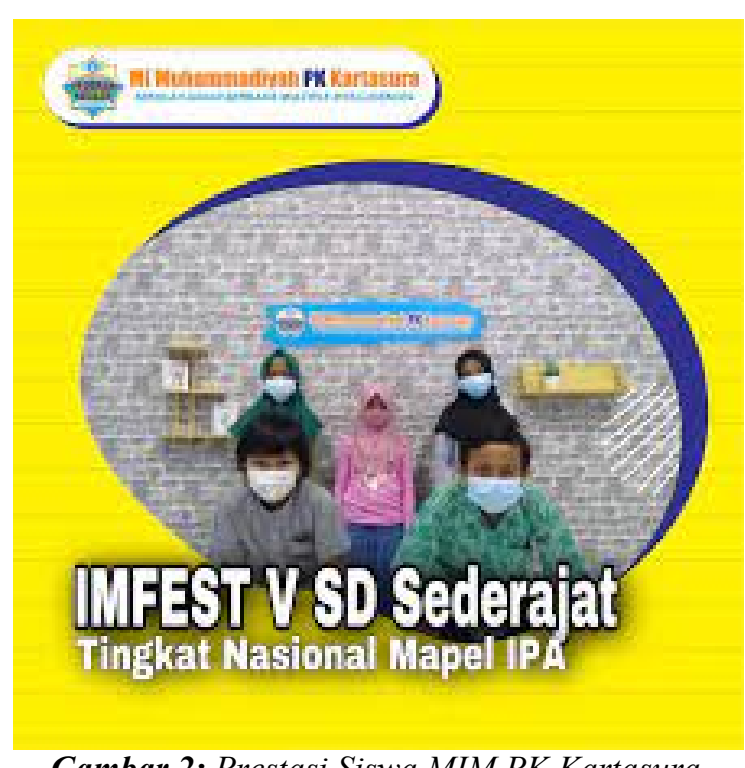

Gambar 2: Prestasi Siswa MIM PK Kartasura 


\section{$a^{2}=$}

Sebagai sekolah unggulan, MI Muhammadiyah PK memiliki program khusus untuk siswa-siswinya antara lain:

\section{Program Khusus Utama}

- Kelas SME (Sains, Math and English)

- Kelas Tahfidz

- Kelas Fullday

26 Program Khusus Penunjang untuk Melejitkan Perkembangan Anak:

1. Alphazone (mengembalikan dalam kondisi alfa/fresh, setiap hari, setiap pagi)

2. Catalyst Day (kurikulum yang ditentukan sendiri oleh anak/siswa)

3. Eksperimen

4. Quality Time (sekolahnya orang tua)

5. Spiritual Building Training

6. Assesment Perkembangan Anak

7. Konsultasi Perkembangan Anak

8. International Student Exchange

9. Outing Class

10. Special Event Hari Besar Nasional

11. Kids Market

12. Seminar Nasional

13. Program Guru Belajar

14. Penerbitan Majalah Sekolah

15. The Most Dilligent Of The Month

16. Penelitian Kecerdasan Majemuk Anak

17. Program Pendamping Baca Tulis

18. Reciting Qur'an dan Iqro' Graduation

19. Listening Qur'an, National Song, Religion Song, Children Song, and Region Song.

20. Special Program For Sixth Grade (Les Pagi, Karantina, Motivasi Belajar Untuk Anak)

21. Multimedia Class

22. Polisi Sekolah

23. Tahfidzul Qur'an dan Hadist

24. Praktek Pembelajaran Lapangan (PPL)

25. Penyambutan Pagi

26. Pembiasaan Budaya Antri

Dari sekian banyak program khusus tersebut tentunya pada masa pandemic covid ini dilaksanakan dengan system terbatas dan menggunakan platform digital.

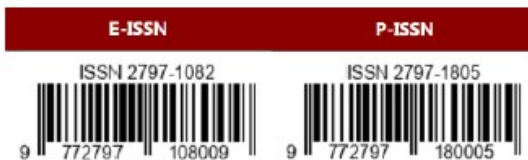

Kurikulum

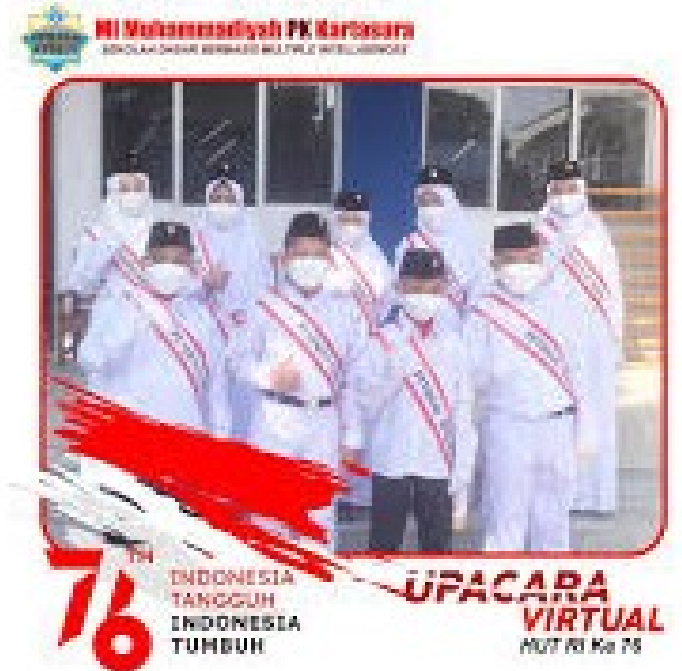

Gambar 3: Upacara HUT RI 76 secara Virtual di MIM PK Kartasura

MI Muhammadiyah PK Kartasura menggunakan kulikurum darurat Pandemi Covid-19, yang mana kurikulum darurat tersebut telah ditetapkan oleh Menteri Pendidikan dan Kebudayaan, Nadiem Makarim.

\section{Durasi Pembelajaran}

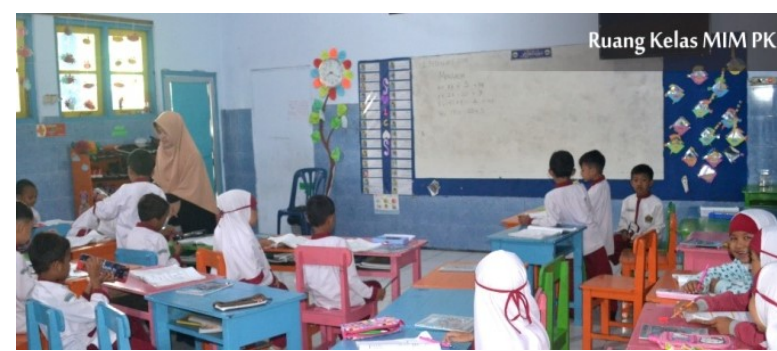

Gambar 4: Proses KBM sebelum Pandemi Covid-19

Durasi pembelajaran dihitung perhari, biasanya sebelum Pandemi siswa menghabiskan waktu belajar $5-6$ jam dalam sehari, namun saat pandemi terjadi perubahan durasi pembelajaran yang mana siswa belajar kurang dari 5 jam setiap harinya.

\section{Jam Kerja Guru dan Karyawan}

Jam kerja guru dan karyawan saat pandemi mengalami pengurangan, hal tersebut disebabkan karena waktu belajar 
murid juga berkurang selama Pandemi. Adanya pengurangan jam kerja guru dan karyawan namun diharapkan guru dan karyawan dapat tetap bekerja dengan maksimal dengan penuh tanggung jawab. Di MIM PK Kartasura mengalami penuruan jam kerja guru dan karyawan $42,85 \%$ dari 7 jam pembelajaran menjadi 4 jam pelajaran.

\section{Implementasi Platform Digital Pembelajaran di MI Muhammadiyah PK Kartasura}

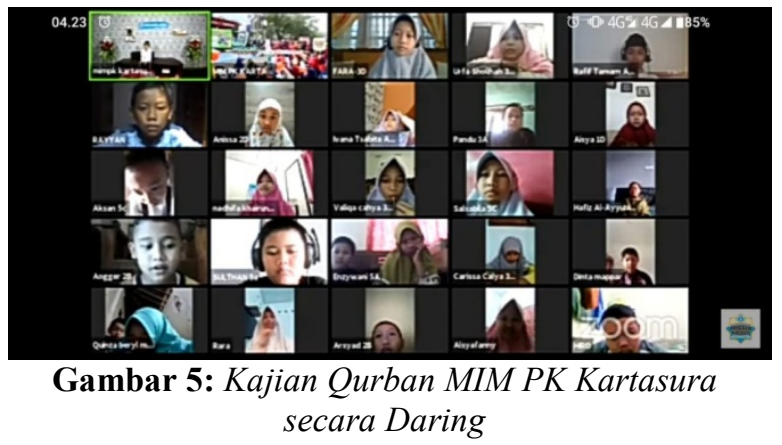

Sebagai sekolah unggulan, MI Muhammadiyah PK Kartasura telah terlebih dahulu menggunakan beberapa platform digital pembelajaran guna mendukung proses kegiatan belajar mengajarnya. Ketika pandemic covid-19 mengharuskan semua sekolah menggunakan platform digital, MIM PK Kartasura seakan-akan tidak asing dengan beberapa media yang ada, terlebih platform digital mitra dari Kementerian dan Kebudayaan.

Namun, diantara platform digital yang paling sering digunakan di MI Muhammadiyah PK Kartasura pada masa Pandemi Covid-19 adalah Google G Suite for Education atau yang lebih popular dengan Google Class Room. Adapun strategi yang dilakukan pihak sekolah, dalam hal ini guru di MIM PK Kartasura adalah dengan membuat bahan pembelajaran seperti modul atau PPT, kemudian menjelaskannya melalui video yang diunggah di platform tersebut.

Alasan penggunaan Google Class Room karena mudah diakses semua kalangan dan mudah dalam penggunaan aplikasinya, selain itu google classroom menawarnan fitur vidio call sehingga komunikasi antar guru dan murid dapat berjalan dengan baik.

Kelemahan dari aplikasi ini, para siswa harus memiliki kuota internet lebih, sehingga guru-guru di MIM PK Kartasura memiliki platform cadangan khusus untuk memberikan materi dan penugasan yakni melalui grup Whatsapp kelas, karena platform media tersebut tidak terlalu membutuhkan kuota dan tersedia juga kuota khusus gratis WA dengan harga terjangkau.

\section{Kesimpulan}

Semua platform digital memiliki kelebihan dan kekurangan, pada intinya semua media akan dapat berfungsi dengan baik apabila ditunjang dengan dukungan materi dari pihak terkait, dalam hal ini pihak sekolah. Sekolah belum dapat mengalokasikan Dana Bantuan Operasional Sekolah untuk menggratiskan kuota internet kepada peserta didik karena belum ada regulasi khusus dalam mengimplementasikan kegiatan tersebut.

Kementerian Pendidikan dan Kebudayaan memberikan kuota gratis kepada seluruh siswa dengan syarat memiliki nomor ponsel aktif yang terdata dalam verval ponsel Kementerian Pendidikan dan Kebudayaan.

Jika daya dukung kuota memadai, maka semua platform mitra Kementerian Pendidikan dan Kebudayaan dapat diimplementasikan sekolah, guru dan peserta didik, tak hanya di MIM PK Kartasura, tapi sekolah-sekolah di seluruh Indonesia.

\section{Saran}

1) Diharapkan MIM PK Kartasura tetap menjaga dan mempertahankan kualitasnya meskipun saat ini masih menerapkan sistem pembelajaran luring dan daring

2) Dikarenakan pandemi maka sistem belajar murid tidak bisa sepenuhnya dapat dipantau dari pihak sekolah maka diiharapkan murid MIM PK Kartasura ikut rutin, mempelajari, dan mengikuti semua materi yang dijelaskan oleh guru. 
3) MIM PK Kartasura yang menerapkan pembelajaran 4-5 jam diharapkan mampu mengikuti peraturan dari pemerintah yaitu 2-3 jam pembelajaran luring dan selanjutnya dapat di lanjut melalui pembelajaran daring.

4) Diharapkan dapat menjadi referensi bagi peneliti selanjutnya dan peneliti selanjutnya diharapkan mampu mengembangkannya lagi.

\section{Daftar Pustaka}

Aji, R. H. S. (2020). Dampak Covid-19 pada Pendidikan di Indonesia: Sekolah, Keterampilan, dan Proses Pembelajaran. SALAM: Jurnal Sosial Dan Budaya Syar-I, 7(5). https://doi.org/10.15408/sjsbs.v7i5.15 $\underline{314}$

Budiwibowo, S., \& Sudarmiani. (2018). Manajemen Pendidikan. Yogyakarta: Andi.

De Porter, Bobbi dan Hernacki, Mike. 1992. Quantum Learning. Membiasakan Belajar Nyaman dan Menyenangkan. Terjemahan oleh Alwiyah Abdurrahman. Bandung: Penerbit Kaifa.

Dyah Pratama, Eryn. 2021. Dampak Pandemi Covid-19 Terhadap Sekolah Muhammadiyah Di Kecamatan Kartasura Kabupaten Sukoharjo. Skripsi. Surakarta: Program Studi Geografi Fakultas Geografi Universitas Muhammadiyah Surakarta.

Fauziddin. 2014. Pembelajaran PAUD Bermain Cerita Menyanyi Secara Islami. Bandung. PT. Remaja Rosda Karya.

Fitriyah, M., \& Luthfiyah. (2018). Metodologi Penelitian. Sukabumi: CV Jejak.

Mukri, S. G. (2020). Modernisasi Sistem Pendidikan di Pesantren. Jurnal Agama Islam, 1-19.
Sawiningsih, S. (2020). Penggunaan Metode Penemuan Untuk Meningkatkan Ketuntasan Belajar Siswa Mata Pelajaran Matematika pada Konsep Penjumlahan Kelas II Semester I SDN Bedoro 2 Sambungmacan. Jurnal Ilmu Pendidikan Fakultas Keguruan dan Ilmu Pendidikan Universitas Sebelas Maret Sukoharjo, Vol.

https://doi.org/10.1093/occmed/kqq06 $\underline{2}$

Sunaryo, P. (2020). Pengembangan Manajemen Kurikulum Pondok Pesantren Modern Adh-Duha Berbasis Yatim dan Dhuafa. Jurnal Tarbawi, 17(1): 2088-3102.

UNICEF. 2020. COVID-19 dan Anak-Anak di Indonesia Agenda Tindakan untuk Mengatasi Tantangan Sosial Ekonomi. In Journal of Education Pshycology and Counseling, 2 (1) Retrieved from www.unicef.org.

Riinawati, R. (2021). Manajemen Pendidikan Pondok pesantren Al Falah Banjarbaru di Masa Pandemi Covid19. Berajah Journal. https://doi.org/10.47353/bj.v1i2.7

Riinawati, R. (2021). Hubungan Konsentrasi Belajar Siswa Terhadap Prestasi Belajar Peserta Didik Pada Masa Pandemi Covid-19 Di Sdn Karang Mekar 4 Banjarmasin. Berajah Journal, 1(2), 81-84. https://doi.org/10.47353/bj.v1i2.8

Santoso, S. 2001.Buku Latihan SPSS: Statiska Multivariat. Elex Media Komputindo, Jakarta.

Sarwono, Jonathan dan Martadiredja, Tutty 2008. Riset Bisnis, Andi, Yogyakarta.

Siagian, P. 2003. Manajemen Sumber Daya Manusia. PT. Bumi Aksara, Jakarta.

Simamora, B. 2004. Panduan Riset Perilaku Konsumen. PT Gramedia Pustaka Utama, Jakarta.

Sudjana, 2004. Penelitian Hasil Proses Belajar Mengajar. Remaja Rosadakarya, Bandung. 
Umar, H. 2004. Metode Penelitian Untuk Skripsi dan Tesis Bisnis. Raja Grafindo Persada, Jakarta.

https://mimpk-kartasura.sch.id/

https://belajar.id/ 